\title{
Pigmented fungiform papillae of the tongue
}

\section{Pigmentowane brodawki grzybowate języka}

\author{
Aleksandra Radomska', Martyna Sławińska², Michał Sobjanek²
}

'Dermatological Students Scientific Association, Faculty of Medicine, Medical University of Gdansk, Poland

2Department of Dermatology, Venereology and Allergology, Faculty of Medicine, Medical University of Gdansk, Poland

'Studenckie Koło Naukowe Gdańskiego Uniwersytetu Medycznego, Polska

${ }^{2}$ Katedra i Klinika Dermatologii, Wenerologii i Alergologii, Wydział Lekarski, Gdański Uniwersytet Medyczny, Polska

Dermatol Rev/Przegl Dermatol 2021, 108, 191-193

DOI: https://doi.org//0.5 | |4/dr.2021. 108613

\section{CORRESPONDING AUTHOR/ ADRES DO KORESPONDENCJI: \\ Aleksandra Radomska \\ Studenckie Koło Naukowe \\ Gdański Uniwersytet Medyczny \\ Gdańsk, Polska \\ e-mail: radomska694@gmail.com}

\begin{abstract}
Introduction: Fungiform papillae are specialized types of papillae found on the surface of the tongue. Pigmented fungiform papillae of the tongue is a mild tongue disorder characterized by a limited discoloration located on fungiform papillae.

Case report: We present a case of a generally healthy 21-year-old woman patient who presented concerned by a pigmented lesion on the tongue. Dermoscopy revealed a distinctive "rose petal pattern" characterized by brown projections with pigmented borders and dichotomized vessels originating at the base. Based on the clinical and dermoscopic features, pigmented fungiform papillae of the tongue were diagnosed, benign lesions requiring no treatment.

Conclusions: This case illustrates the role of mucous membrane dermoscopy (mucoscopy) in differential diagnosis of pigmented oral lesions.
\end{abstract}

\section{STRESZCZENIE}

Wprowadzenie: Brodawki grzybowate występują na powierzchni języka. W ich obrębie znajdują się kubki smakowe, które odpowiadają za odczuwanie gorzkiego smaku oraz receptory temperatury.

Opis przypadku: Przedstawiamy przypadek ogólnie zdrowej, 21-letniej pacjentki, która zgłosiła się z powodu zmiany barwnikowej na języku. W obrazie dermoskopowym stwierdzono centralne skupienie pigmentu ze zbieleniem na obwodzie typu „objawu płatka róży”. Na podstawie obrazu klinicznego i dermoskopowego rozpoznano pigmentowane brodawki grzybowate języka (pigmented fungiform papillae of the tongue), zmiany łagodne niewymagające leczenia.

Wnioski: Opisany przypadek ilustruje znaczenie badania dermoskopowego błony śluzowej (mukoskopii) w diagnostyce różnicowej zmian barwnikowych jamy ustnej.

Key words: dermoscopy, fungiform papillae, melanoma, oral mucous membrane, rose petal pattern, tongue.

Słowa kluczowe: dermatoskopia, brodawki grzybowate języka, czerniak, membrana błony śluzowej jamy ustnej, "objaw płatka róży", język. 


\section{INTRODUCTION}

Fungiform papillae belong to the specialized types of papillae found on the surface of the tongue. On their surface there are taste buds (responsible for the bitter taste) and temperature receptors. They are located on the upper and lateral surfaces of the tongue. They are usually flat and pink [1].

Pigmented fungiform papillae of the tongue (PFPT) is a mild tongue disorder. It is characterized by a limited discoloration located on fungiform papillae [2].

The incidence of PFPT varies in different populations. While PFPTs are relatively common in populations with dark skin phototypes, their incidence in the Caucasian population appears to be extremely rare.

\section{CASE REPORT}

We present a case of a generally healthy 21-yearold woman with skin phototype II, who reported to the outpatient clinic at the Department of Dermatology because of a pigmented lesion in her tongue, concerned about the possibility of melanoma (fig. 1 A). The exact time of onset was unknown. Personal and family history of melanoma was negative. The videodermoscopic image showed a central concentration of pigment with whitening on the perimeter, referred to in the literature as a "rose petal" pattern (fig. 1 B) [3]. Due to the patient's anxiety, the lesion was qualified for videodermoscopic observation. Absence of changes in the clinical and dermoscopic presentation from the perspective of 1-year observation confirmed the mild nature of the lesion.
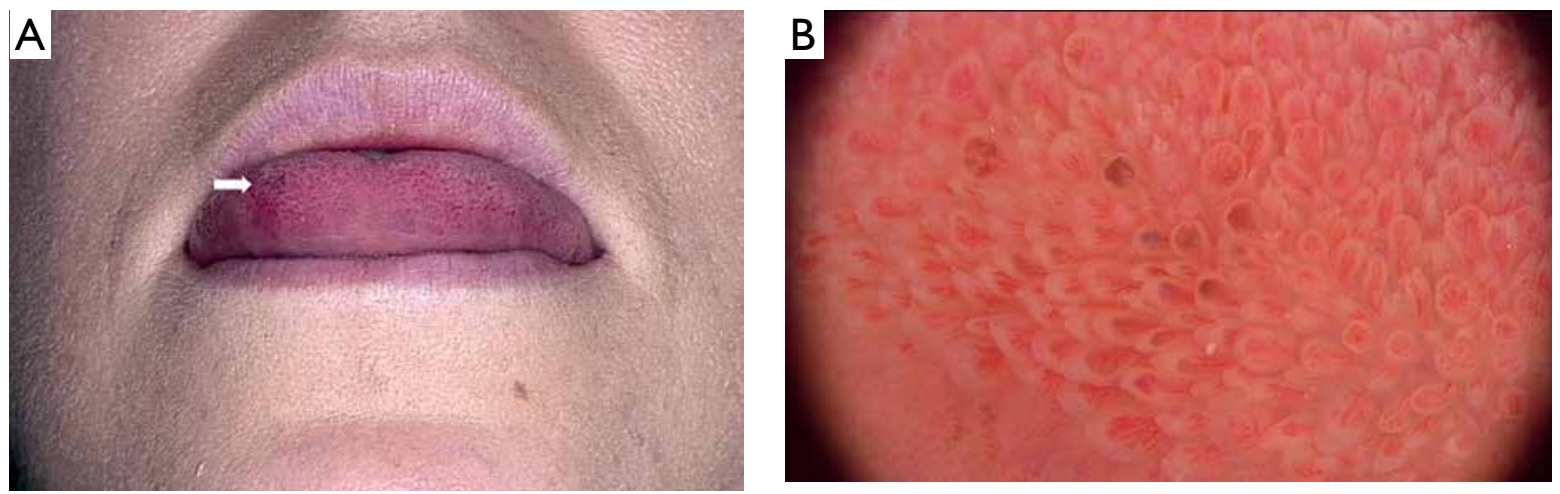

Figure I. A - Clinical presentation. Pigmentation limited to the fungiform papillae of the tongue, with irregularly distributed spots on the anterolateral surface of the tongue. B - Dermoscopic image. Visible pigmented lingual papillae with vessels branching from the base to form a rose petal-like appearance (FotoFinder, 20x, unpolarized light dermoscopy)

Rycina I. A - Obraz kliniczny. Pigmentacja ograniczona do grzybowatych brodawek języka, z nieregularnie rozmieszczonymi ogniskami na przednio-bocznej powierzchni języka. B - Obraz dermoskopowy. Widoczne zabarwione brodawki językowe z rozgałęziającymi się od podstawy naczyniami, co tworzy wygląd podobny do płatka róży (FotoFinder, 20x, dermoskopia ze światłem niespolaryzowanym) 


\section{DISCUSSION}

The etiopathogenesis of the disease remains unknown. PFPR most often occurs between the ages of 20 and 30, sporadically in children [4]. Three variants of PFPT have been distinguished: hyperpigmentation involving all fungiform papillae and affecting the anterolateral surface or tip of the tongue, discoloration of 3-7 fungiform papillae randomly distributed on the dorsal surface of the tongue, and hyperpigmentation of all fungiform papillae on the dorsal surface of the tongue. The second type is the most common one, including selected papillae on the dorsal surface of the tongue, as in the presented case [5]. Hyperpigmentation is associated with the presence of melanin in macrophages of fibrous subepithelial connective tissue. There is no evidence of inflammation or proliferation of melanocytes [2].

The differential diagnosis should involve: pernicious anemia, haemochromatosis, Peutz-Jeghers syndrome, Addison's disease, Laugier-Hunziker syndrome, melanocytic nevus, melanoma, black hairy tongue, and amalgam tattoo [2]. These conditions can be distinguished from PFPT by history, accompanying symptoms, and results of additional laboratory tests. If pigmentation is on areas of the tongue containing taste buds and there are no associated symptoms, then PFPT should be considered first. Dermoscopic image is helpful in confirming the initial clinical diagnosis. Invasive examinations and treatment are not necessary. In patients who present themselves for aesthetic reasons, excisional biopsy may be performed both to confirm the diagnosis and to treat it.

\section{CONFLICT OF INTEREST}

The authors declare no conflict of interest.

\section{OMÓWIENIE}

Etiopatogeneza PFPT jest nieznana. Schorzenie najczęściej występuje między 20. a 30. rokiem życia, sporadycznie u pacjentów pediatrycznych [4]. Wyróżniono trzy warianty PFPT: hiperpigmentację obejmującą wszystkie brodawki grzybowate i dotyczącą przednio-bocznej powierzchni lub końca języka, przebarwienie dotyczące 3-7 brodawek grzybowatych rozmieszczonych losowo na grzbietowej powierzchni języka oraz hiperpigmentację wszystkich brodawek grzybowatych na grzbietowej powierzchni języka. Najczęściej występuje typ drugi obejmujący wybrane brodawki na grzbietowej powierzchni języka, jak w prezentowanym przypadku [5]. Hiperpigmentacja wiąże się z obecnością melaniny w makrofagach włóknistej podnabłonkowej tkanki łącznej. Nie stwierdza się cech stanu zapalnego lub proliferacji melanocytów [2].

W diagnostyce różnicowej należy uwzględnić anemię złośliwą, hemochromatozę, zespół Peutza-Jeghersa, chorobę Addisona, zespół Laugiera-Hunzikera, znamiona melanocytowe, czerniaka, język czarny włochaty i tatuaż amalgamatowy [2]. Stany te można odróżnić od PFPT na podstawie wywiadu, objawów towarzyszących oraz wyniku dodatkowych badań laboratoryjnych. Jeśli pigmentacja znajduje się na częściach języka zawierających kubki smakowe i nie występują objawy towarzyszące, to $\mathrm{w}$ pierwszej kolejności należy rozważyć PFPT. Obraz dermoskopowy jest pomocny w potwierdzeniu wstępnego rozpoznania klinicznego. Inwazyjne badania i leczenie nie są konieczne. U pacjentów, którzy zgłaszają się z przyczyn estetycznych, można wykonać biopsję wycinającą, zarówno w celu potwierdzenia rozpoznania, jak i leczenia.

\section{KONFLIKT INTERESÓW}

Autorzy nie zgłaszają konfliktu interesów.

\section{References}

\section{Piśmiennictwo}

1. Chessa M.A., Patrizi A., Sechi A., Virdi A., Leuzzi M., Neri I.: Pigmented fungiform lingual papillae: dermoscopic and clinical features. J Eur Acad Dermatol Venereol 2018, 32, 935-939.

2. Smogorzewski J.M., Armstrong P., Young L.: Pigmented fungiform papillae of the tongue in an Indian male. Cutis 2019, 103, E16-E17.

3. Chamseddin B., Vandergriff T.: Pigmented fungiform papillae of the tongue: a clinical and histologic description. Dermatol Online J 2019, 25, 13030/qt8674c519.

4. García Martínez F.J., López Martín I., Segurado Rodríguez M.A.: Pigmentación de las papilas fungiformes linguales. Rev Pediatr Aten Primaria 2015, 17, e205-e207.

5. Sugiyama Y., Hayashi K., Takayama T.: Pigmented fungiform papillae of the tongue in a Japanese child. Clin Case Report 2020, 8, 1104-1106.

Received: 15.05 .2021

Accepted: 2.06.2021

Otrzymano: 15.05.2021 r

Zaakceptowano: $2.06 .2021 \mathrm{r}$.

How to cite this article:

Radomska A., Sławińska M., Sobjanek M.: Pigmented fungiform papillae of the tongue. Dermatol Rev/Przegl Dermatol 2021, 108, 191-193. DOI: https://doi.org/10.5114/dr.2021.108613. 